\title{
Implications of the Tiebout Hypothesis For Residential Property Valuation Within Small Metropolitan Regions: An Empirical Analysis
}

\author{
RoBert PREMUs* \\ INTRODUCTION
}

The Tiebout hypothesis states that residential population mobility provides an important equilibrating mechanism leading to an efficient supply of local government services." Migrants are viewed as "voting with their feet" for public services as they shop among communities for a residence that offers the desired level and mix of public services. Thus, in the Tiebout model, policies that reduce fiscal choices by migration (e.g., establishing metropolitan government through jurisdictional consolidation) result in allocative inefficiencies.

Some empirical evidence supporting the Tiebout hypothesis was provided by Oates' test on fifty-three northeastern New Jersey communities surrounding New York City. Oates [1969] found that local property tax rates and per pupil expenditures (a proxy for local government output) were statistically significant explanatory variables in a regression equation-an equation that controlled for community accessibility to New York City, housing quality and neighborhood effects-that attempted to explain intercommunity differentials in residential property values. Oates postulated that if high property tax rates discourage in-migration and encourage out-migration, other things equal, residential property values will decline reflecting a decline in aggregate demand for residential real estate. Since public expenditures confer positive benefits on property owners, residential property values and the level of public expenditures should be positively related. Thus, Oates interpreted the negative coefficient for local property tax rates and the positive coefficient for per pupil expenditures in his study as supportative evidence for the Tiebout hypothesis. ${ }^{2}$

Oates' test has several weaknesses that may vitiate its tentative support for the Tiebout hypothesis. First, local government taxes other than local property taxes contribute to the cost of homeownership among communities. Thus, by excluding non-property taxes (e.g., income and sales taxes), Oates may have seriously understated the offer price for public services among communities. Second, although the level and quality of educational services among communities may be a significant locational factor, the level and mix of other municipal services (e.g., police and fire protection) may significantly affect property values. Third, Oates postulated and found a negative relationship between community access to New York City and median residential property values (lots and structures). Although

*Assistant Professor, Wright State University, Dayton, Ohio. 
the value of land may be expected to fall with distance from the central city, reflecting rising transportation costs, the value of structures may rise. If residential suburbanization is primarily a high income phenomenon, the income effects (of both a higher median family income and a reduction in the price of land) may result in increasing expenditures on housing within suburban communities. Moreover, if high income individuals seek spatial isolation as a form of community differentiation, or as an implicit discriminating device, land values would be expected to rise in peripherial communities within metropolitan regions. Thus, the relationship between distance and median property values is indeterminant. Finally, to control for housing quality and neighborhood effects, Oates selected a subset of proxy variables from a much larger set of interdependent housing and neighborhood variables (e.g., size of dwellings and median family income). Although based on a priori considerations, such as a procedure for variable selection is arbitrary and may result in the omission of important explanatory variables and/or multicollinearity problems.

In this paper, the weakness of Oates' test are overcome and the adjusted Oates' model is applied to explain residential property value differentials among communities within the Harrisburg, Pennsylvania, area. Besides aggregative measures of community tax rates and public expenditure levels, the Harrisburg test utilizes the piinciple component model to select variables to control for housing quality and neighborhood effects. Also, the sign of the distance-from-central-city-variable is postulated to be indeterminant since it depends upon the relative strength of conflicting forces.

\section{THE MODEL}

The model to be tested empirically in this study may be expressed as follows:

$$
\mathrm{X}_{1}=\mathrm{f}\left(\ln \mathrm{X}_{2}, \ln \mathrm{X}_{3}, \ln \mathrm{X}_{4}, \mathrm{X}_{5}, \ldots \mathrm{X}_{19}\right)
$$

where:

$\mathrm{X}_{1}=$ Median value of owner-occupied dwellings (lot and structure). $\ln X_{2}=$ The natural log of aggregate effective property tax rates. $\ln \mathrm{X}_{3}=$ The natural log of aggregate municipal and school expenditures. $\ln \mathrm{X}_{4}=$ The natural log of linear distance to City of Harrisburg.

$\mathrm{X}_{\mathrm{i}}=$ Percentage of housing units deemed sound by the 1960 census takers.

$\mathrm{X}_{6}=$ Percentage of dwellings owner-occupied.

$\mathrm{X}_{\bar{T}}=$ Percentage of families with income less than $\$ 3000$.

$\mathrm{X}_{s}=$ Median number of school years completed by males 25 or over.

$\mathrm{X}_{9}=$ Degree of occupational homogeneity.

$\mathrm{X}_{10}=$ Percentage change in population from 1950 to 1960.

$\mathrm{X}_{11}=$ Annual median family income.

$\mathrm{X}_{12}=$ Median number of rooms per dwelling.

$\mathrm{X}_{13}=$ Housing vacancy ratio.

$\mathrm{X}_{1+}=$ Percentage of housing units with 1.01 or more persons per room.

$\mathrm{X}_{1,}=$ Percentage of residents (gross) that moved into owner-occupied units from 1958-60. 
$\mathrm{X}_{16}=$ Population per square mile.

$\mathrm{X}_{1 \tau}=$ Percentage of housing units existing in 1960 built since 1950.

$\mathrm{X}_{1 \mathrm{~s}}=$ Industrial concentration ratio (ratio of industrial and commercial acreage to total acreage).

$\mathrm{X}_{19}=$ School enrollment as a percentage of total community population.

Data for the empirical test are based on a 1960 cross-sectional study of nineteen variables for fourteen communities with a population of 2,500 or more surrounding the City of Harrisburg. The dependent variable, $\mathrm{X}_{1}$, used in the test is residential property values which is represented by the median value of owner-occupied dwellings (lot and structure). These values are based upon owner appraisals taken from the 1960 Census of Housing [1960, Table 26]..$^{3}$ The explanatory variables in the regression equation include $\ln \mathrm{X}_{2}$, the natural $\log$ of aggregate effective property tax rates, and $\ln \mathrm{X}_{3}$, the natural log of aggregate municipal and school expenditures. The natural $\log$ of the linear distance to the City of Harrisburg, $\ln \mathrm{X}_{4}$, represents the accessibility of each community relative to the central city. ${ }^{4}$ The variables $\mathrm{X}_{5}$ to $\mathrm{X}_{19}$ serve as indices of the social and economic dimensions of the communities.

The effective tax rate, $\ln \mathrm{X}_{2}$, is intended to measure the tax-price of consuming public services in each community. It is an aggregate of the effective tax rates for school and municipal services and is calculated by expressing total tax collections irom property and non-property tax sources for school and municipal services as a percentage of the estimated market value of the real property in the communities. ${ }^{5}$ This measure of community tax rates represents the cost of homeownership in a community to the average citizen ${ }^{6}$ on the assumption that the burden of local taxes of all types rests upon the property owners of the levying jurisdiction. Thus, we would expect $\ln \mathrm{X}_{2}$ to be inversely related to $\mathrm{X}_{1}$.

The level of public service consumption, $\ln \mathrm{X}_{3}$, is approximated by summing municipal expenditures per capita and school expenditures pér pupil. Education service levels are approximated by expenditures per pupil rather than per capita since per capita school expenditures are sensitive to intercommunity differences in the age composition of the population. Aggregate government expenditures (educational and municipal) are used as the measure of the level of total government services associated with home ownership in one community as opposed to another. ${ }^{8}$ Thus, $\ln \mathrm{X}_{3}$ should be positively correlated with $\mathrm{X}_{1}$.

Accessibility to the major business district, shopping centers, educational institutions and areas of entertainment and recreation, as measured by $\ln \mathrm{X}_{+}$(the linear distance from the center of each community to the City of Harrisburg), is expected to contribute to the locational advantage of a community. ${ }^{9}$ If the main social, cultural and business activities within the Harrisburg metropolitan region are concentrated in the City of Harrisburg, communities located closer to the central city, as measured by a lower $\ln \mathrm{X}_{4}$, are expected to have higher property values reflecting the savings in commuting costs and a reduction in mental and physical stress from traveling.

Property values may, however, rise with linear distance from the central city. If employment, recreational and shopping opportunities are dispersed randomly 
throughout the metropolitan region, proximity of a community to the City of Harrisburg becomes less important in determining property values. In this case, the fiscal advantages of the suburbs may attract higher income individuals and we would expect property values and distance from the City of Harrisburg to be positively related.

Community characteristics are measured by variables $\mathrm{X}_{5}$ to $\mathrm{X}_{1, !}$. Since many of these variables may measure the same community characteristic, the inclusion of all of them may result in multicollinearity. In order to avoid this problem, the first stage of principal component analysis is applied to variables $\mathrm{X}_{5}$ and $\mathrm{X}_{1 \text {. }}$.

Four components, or sets of highly intercorrelated variables, which depict community attributes are extracted and represented in the test by the variable with the highest loading on each component. ${ }^{10}$ In particular, the first component consisting of variables $X_{i}$ through $X_{11}$, neighborhood quality, is represented by median family income $\left(\mathrm{X}_{11}\right)$. High neighborhood quality (median family income), which is a function of the social, economic and physical characteristics of community population and activities, is expected to, ceteris paribus, positively influence residential property values.

The second component consisting of variables $\mathrm{X}_{12}$ through $\mathrm{X}_{16}$, the inverse of housing quality, is represented by the percentage of housing units with 1.01 or more persons per room $\left(\mathrm{X}_{14}\right)$. High quality (valued) residential property is expected to have a lower percentage of dwellings with 1.01 or more persons per room than low quality (valued) residential property.

The future of the community as a residential site, component three consisting of variables $\mathrm{X}_{1 \tau}$ and $\mathrm{X}_{18}$, is represented by the industrial concentration ratio $\left(\mathrm{X}_{1:}\right)$, which measures the proportion of total community acreage devoted to industrial and commercial uses. Communities characterized by a low ratio of industrial and commercial activities are expected to be attractive residential sites, ceteris paribus.

Finally, the age composition of the population, the fourth component, is represented by the school enrollment ratio $\left(\mathrm{X}_{19}\right)$ which measures the proportion of a community's population attending elementary and secondary schools. Other things equal, potential migrants who are likely to be in the twenty to thirty age group are expected to prefer communities with a lower percentage of the aged population.

\section{EMPIRICAL RESULTS-TWO STAGE LEAST SQUARES}

The two-stage least squares technique (2SLS) is used to analyze the determinants of intercommunity residential property value differentials. Tax rates $\left(\ln \mathrm{X}_{2}\right)$, public expenditures $\left(\ln \mathrm{X}_{3}\right)$ and property values $\left(\mathrm{X}_{1}\right)$ are assumed to be endogenous variables in a three equation system so that their values must be simultaneously determined. Variables $\ln \mathrm{X}_{4}$ through $\mathrm{X}_{1,}$, are treated as exogenous variables in the complete system; exogeneous variables influence the endogenous variables and the error term but they are not, in turn, influenced by these factors.

The first stage in estimating the equation for property values in the 2SLS model is to regress $\ln \mathrm{X}_{2}$ and $\ln \mathrm{X}_{3}$ respectively on all predetermined variables in 
the system to obtain $\ln \hat{\mathrm{X}}_{2}$ and $\ln \hat{\mathrm{X}}_{3} \cdot \ln \hat{\mathrm{X}}_{2}$ and $\ln \hat{\mathrm{X}}_{3}$ are the predicted values for the natural log of effective tax rates and public expenditures that are "purged" of their association with the error term. ${ }^{11}$ The second stage involves the application of OLS to estimate the property value equation that includes the "purged" measures of $\ln \mathrm{X}_{2}$ and $\ln \mathrm{X}_{3}$ along with other variables. ${ }^{12}$

The results of 2SLS analysis are presented in Table I. Variables for the test are listed in Column (1). The regression coefficients for the various equations, including Oates' model, are shown in Columns (2)-(5). The computed t-ratios are in parenthesis beneath the estimated regression coefficients, and $\bar{R}^{2}$ (i.e., $\mathrm{R}^{2}$ adjusted for degrees of freedom) and the degrees of freedom (d.f.) for each test are at the bottom of the appropriate column.

Column (2) represents the results of the 2SLS regression model used by Oates for fifty-three northeastern New Jersey communities. Column (3) represents an application of Oates' model to the Harrisburg metropolitan region. Our 2SLS model is identical with Oates' model except for the measures of effective tax rates and municipal output. ${ }^{13}$ All of the regression coefficients in Oates' study are of the expected sign and they are significant at a 5 percent level. In contrast, only median family income $\left(\mathrm{X}_{11}\right)$, community public expenditures $\left(\ln \hat{\mathrm{X}}_{3}\right)$, and community location $\left(\ln \mathrm{X}_{4}\right)$ are statistically significant at a 5 percent level in the Harrisburg test of Oates' model.

One reason for the poor results may be that Oates' regression model is not properly specified. In particular, whereas a large number of socio-economic variables representing non-fiscal community characteristics may affect property values, Oates selects only a subset of these variables. This technique introduces arbitrariness into the regression model and thus may account for the poor statistical results obtained when Oates' model is applied to the Harrisburg area.

Thus, misspecification of the model and multicollinearity are suspected difficulties that are plaguing the 2SLS test of Oates' model in the Harrisburg area. A properly specified regression model, as previously discussed, should include measures of community components as regressors in the property value equation. Also, community components as regressors reduces multicollinearity because the components are statistically independent.

Column (4) of Table I is the best of a series of 2SLS tests that are obtained when community components are included as regressors. The coefficient for local tax rates $\left(\ln \hat{X}_{2}\right)$ is negative and statistically significant at a five percent level. The coefficient for local public expenditures $\left(\ln \hat{X}_{3}\right)$ is positive and almost significant at the ten percent level (the critical t-ratio is 1.34). A positive coefficient for community location in nonlog form $\left(\mathrm{X}_{4}\right)$ which is statistically significant at the five percent level, indicates that property values tend to increase with distance from the central city.

Several community attributes are also significantly associated with median property values in this test. The coefficient for neighborhood quality, represented by median family income $\left(\mathrm{X}_{11}\right)$, is positive and statistically significant at a five percent level of significance. The percentage of housing units with 1.01 or more 


\section{TABLE I}

2SLS Tests of Property Value Equations in the Harrisburg Metropolitan Region

\begin{tabular}{|c|c|c|c|c|}
\hline $\begin{array}{l}\text { Variables } \\
\text { (1) }\end{array}$ & $\begin{array}{c}\text { Oates' } \\
\text { Model } \\
(2)\end{array}$ & (3) & 2SLS Equations & (5) \\
\hline Constant & -29 & -95148.03 & -5946.92 & -3719.61 \\
\hline $1 n \hat{X}_{2}$ & $\begin{array}{c}-3.6 \\
(3.1)\end{array}$ & $\begin{array}{c}-11711.14 \\
(.69)\end{array}$ & $\begin{array}{c}-11730.24 \\
(2.75)^{*}\end{array}$ & $\begin{array}{c}16483.88^{\mathrm{b}} \\
(3.47)^{*}\end{array}$ \\
\hline $\ln \hat{\mathrm{X}}_{3}$ & $\begin{array}{c}4.9 \\
(2.1)\end{array}$ & $\begin{array}{r}14958.32 \\
(2.05) *\end{array}$ & $\begin{array}{l}6423.71 \\
(1.34) * *\end{array}$ & \\
\hline $\ln \mathrm{X}_{4}$ & $\begin{array}{l}-1.3 \\
(4.0)\end{array}$ & $\begin{array}{c}1078.64 \\
(1.96) *\end{array}$ & $\begin{array}{l}172.10^{\mathrm{a}} \\
(4.23)^{*}\end{array}$ & $\begin{array}{r}175.25 \\
(5.26)^{*}\end{array}$ \\
\hline $\mathrm{X}_{7}$ & $\begin{array}{c}.3 \\
(3.1)\end{array}$ & $\begin{array}{c}187.82 \\
(.54)\end{array}$ & & \\
\hline $\mathrm{X}_{11}$ & $\begin{array}{l}1.5 \\
(7.7)\end{array}$ & $\begin{array}{l}2.90 \\
(2.85) *\end{array}$ & $\begin{array}{l}2.27 \\
(5.08) *\end{array}$ & $\begin{array}{l}2.27 \\
(5.24)\end{array}$ \\
\hline $\mathrm{X}_{12}$ & $\begin{array}{c}1.6 \\
(3.6)\end{array}$ & $\begin{array}{c}4678.14 \\
\quad(.87)\end{array}$ & & \\
\hline $\mathrm{X}_{14}$ & & & $\begin{array}{c}-689.39 \\
(2.99) *\end{array}$ & $\begin{array}{l}-719.81 \\
(3.48) *\end{array}$ \\
\hline $\mathrm{X}_{17}$ & $\begin{array}{l}.06 \\
(3.9)\end{array}$ & $\begin{array}{l}69.80 \\
(.83)\end{array}$ & & \\
\hline $\mathrm{X}_{18}$ & & & $\begin{array}{r}-1.26 \\
(.03)\end{array}$ & $\begin{array}{l}4.07 \\
(.13)\end{array}$ \\
\hline $\mathbf{X}_{19}$ & & & $\begin{array}{r}-0.06 \\
(.05)\end{array}$ & $\begin{array}{l}7.45 \\
(.05)\end{array}$ \\
\hline d.f. & 45 & 6 & & 7 \\
\hline$\overline{\mathrm{R}}=$ & .92 & .74 & .89 & .89 \\
\hline
\end{tabular}

\footnotetext{
*Statistically significant at the five percent level for a one-tail test ( $t$-ratios in parentheses).

**:Statistically significant at the ten percent level for a one-tail test ( $t$-ratios in parentheses). aCoefficient for community location in non-log form.

hCoefficient of the natural $\log$ of the ratio of the "purged" tax and expenditure variables.
}

persons per room $\left(\mathrm{X}_{14}\right)$, a proxy for the inverse of housing quality, has a negative regression coefficient that is statistically significant at the five percent level. Variables $\mathrm{X}_{1 .}$ (the industrial concentration ratio) as a proxy for the potential of the community as a future residential site and $\mathrm{X}_{1: 1}$ (the school enrollment ratio) as a proxy for the age composition of the population are not statistically significant at a reasonable level. Finally, the regression model accounts for 95 percent of the variation in median property values and all of the coefficients are of the expected sign (adjusted $\overline{\mathrm{R}}^{-2}=.89$ ).

A regression model can be evaluated in terms of the magnitude of its regression coefficients as well as by its statistical properties. The magnitude of the coefficients in Column (4) of Table I are examined for the "typical" community by analyzing the impact of changes in each of the independent variables on median pioperty values. 
The coefficient for $\ln \hat{\mathrm{X}}_{2}$ in Column (4) of Table I, -17730.24, indicates that an increase in aggregate effective local tax rates from 17 percent (the mean) to 18 percent, other things equal, results in a decline of approximately $\$ 669$ in median property values. ${ }^{14}$ For the "typical" community, which has a market valuation of real property of approximately $\$ 21$ million and a population of about 6,500 people, the one percentage point tax increase generates a $\$ 32$ per capita tax bill (a $\$ 0.21$ million increase in tax collection divided by a population of 6,500 ). Thus, an increase in per capita taxes of $\$ 32$ leads to a $\$ 669$ decline in residential property values.

The coefficient for $\ln \hat{X}_{3}$ provides some empirical evidence that the final incidence of local taxes depends upon the uses to which the tax proceeds are put. A one percentage point tax hike for the typical community with a balanced budget will generate a $\$ 32$ increase in per capita municipal and per pupil school services. A rise in local government expenditures by $\$ 32$ from $\$ 400$ (the mean) to $\$ 432$, other things equal, will push up median property values by approximately $\$ 494.63$ (the difference between the natural log of 400 and 432 times the regression coefficient of 6423.74). ${ }^{15}$ However, we already calculated that property values would decline by $\$ 669$ for an equal rise in per capita taxes. Apparently, the value of benefit flows from local government tax proceeds in the Harrisburg area is somewhat less than the capitalized value of the tax burden. ${ }^{16}$

The coefficient for linear distance in non-log form $\left(\mathrm{X}_{+}\right), 172$, indicates that property values (within the Harrisburg SMSA) rise by approximately $\$ 172$ for each successive mile from the center of the City of Harrisburg. ${ }^{17}$ This increase in property values might reflect the capitalized value of dollar savings in transportation costs from being closer to suburban and rural employment opportunities and outdoor activities, the higher fiscal surplus in the suburbs, and a premium that individuals place on suburban livings, or a combination of these factors.

Community attributes also affect property valuation as expected in the test. The coefficient $(2.72)$ for median family income $\left(\mathrm{X}_{11}\right)$ indicates that neighborhood quality is an important consideration when home buyers choose among community locations. It suggests that a rise of $\$ 1,000$ in median family income will lead to a rise in property values of approximately $\$ 2,270$. This may simply reflect a factor of proportionality of two or three between the value of one's home and annual income. ${ }^{1 .}$ This is equal to a perpetual annual stream of income of $\$ 181.60$ capitalized at eight percent.

The inverse of community housing quality is represented in the regression model by the percentage of dwellings with 1.01 or more persons per room $\left(\mathrm{X}_{14}\right)$. The coefficient for $\mathrm{X}_{1 \downarrow},-689.39$, implies that a one percent rise in the percentage of dwellings with 1.01 or more persons per room results in a reduction in property values of approximately $\$ 689$. Thus, the availability of living space and the degree of residential privacy appear to be important factors in the individual's residential choice calculus.

Community potential as a future residential site $\left(\mathrm{X}_{1 \times}\right)$ and the age composition of the population $\left(\mathrm{X}_{1,1}\right)$ are hypothesized to be important locational variables but coefficients for their proxies, variables $\mathrm{X}_{1 \times}$ and $\mathrm{X}_{1,}$, respectively, are not signi- 
ficant at a reasonable level of significance. They are retained in the analysis so that the model is completely specified although their exclusion did not significantly influence the coefficients of the retained variables.

Column (4) of Table I is the last 2SLS test of the model. It is identical to Column (5) of Table I except that local government tax rates and public service levels are omitted as separate explanatory variables in favor of the ratio of local public expenditures to local tax rates $\left(\ln \hat{\mathrm{X}}_{:} / \ln \hat{\mathrm{X}}_{2}\right)$. The ratio serves as a rough direct measure of unequal fiscal surplus among the jurisdictions. Buchanan demonstrates that individuals located in communities with an above average tax base have a higher fiscal surplus-defined as the difference between total taxes paid and total benefits received-relative to their equals in the less fiscally healthy communities. ${ }^{19}$ These fiscal advantages should, therefore, be reflected by variations in the ratio of public expenditures to tax rates between communities. Individuals are expected to respond to variations in fiscal surplus, and as a result, residential property values should rise to reflect the present discounted value of the higher fiscal surplus values encountered in the wealthier communities.

The test in Column (5) of Table I provides some direct evidence that horizontal fiscal inequities are reflected in median property values. The coefficient for $\ln \hat{\mathrm{X}}_{:} / \ln \hat{\mathrm{X}}_{2}, 16483.88$, is positive and statistically significant at a five percent level. The significance (or lack of significance) of the other explanatory variables does not change from Column (4) to Column (5) although the absolute size of the coefficients for $\mathrm{X}_{1 .}$ and $\mathrm{X}_{1}$ are affected to a great extent. A coefficient on $\ln \hat{\mathrm{X}}_{4} /$ $\ln \hat{X}_{2}$ of 16483.88 suggests that a rise in this variable by .01 from 2.11 to 2.12 will push up property values by $\$ 165$. A .01 increase in this variable can be the result of an increase in public expenditures per capita by approximately $\$ 12$ while holding tax rates constant. The $\$ 12$ reflects the value of horizontal fiscal inequities from residing in a community with an index of fiscal surplus (as measured above) .01 higher than the average ratio (2.11). A $\$ 12$ perpetual annual stream of benefits capitalized at eight percent is worth $\$ 150$ implying that approximately 91 percent of the fiscal gains from residing in the more affluent communities are capitalized, at this discount rate, into higher property values.

\section{SUMMARY AND CONCLUSIONS}

Empirical factors underlying 1960 residential property value differentials among communities within small metropolitan regions were investigated in this paper. Our purpose was to improve on several features of Oates' test of the Tiebout model for large metropolitan regions (e.g., New York City), to apply the modified Oates' model to the Harrisburg metropolitan region, and to examine the empirical implications of the Tiebout model for residential property valuation via tax and expenditure capitalization effects.

The empirical results suggest that the final incidence of a local tax increase depends upon how residents view the additional tax-financed public expenditures generated by the tax increase. Also, some empirical evidence was found that unequal total fiscal surplus between communities, due to unequal community afflu- 
ence, affects migration behavior. Thus, it would appear that Tiebout's model has some empirical relevance within small metropolitan regions.

In addition, residential property values within the Harrisburg SMSA were found to be positively related to linear distance from the City of Harrisburg; whereas, property values were a declining function of distance in Oates' test. Moreover, community amenities (which were measured with the aid of the principle component model) such as neighborhood quality, degree of privacy, and social stability were also found to significantly affect residential property values. Thus, it would appear that residential choice behavior and property valuation are considerably more complex phenomena than is suggested in the simple Tiebout model.

Finally, this study supports arguments against public policies that would create a metropolitan government to the extent that public sector choices would be reduced. By impairing the mechanism whereby individuals "vote with their feet" and "trade with their feet" a welfare loss may be incurred if metropolitan government replaces local government decentralization. However, removing interpersonal and intercommunity inequities by fiscal transfers is a necessary complement to local government decentralization if population mobility is to perform efficiently as an allocative mechanism in the local public sector. Also, since Tiebouts' migrants (including the poor) should be geographically indifferent to location for reasons other than their preferences for public goods, the provision of health and welfare services-not just uniform welfare payments-for the poor in wealthy suburban and wealthy rural communities (as well as in poor communities), geographically discriminatory rent supplements, and subsidized mass transportation facilities may be desirable public policies.

\section{FOOTNOTES}

1 Tiebout [1956].

-Hyman and Pasour [1973] applied Oates' model to North Carolina communities, but because of the relative insignificance of local responsibility for educational services and local property taxes, the implications of the test for Tiebout's model are inclusive. Both variables were statistically significant and of the expected sign, but the magnitude of the regression coefficients was small.

:Variables $\mathrm{X}_{5}, \mathrm{X}_{14}$, and $\mathrm{X}_{15}$ listed below are also taken from Table 26. Variables $\mathrm{X}_{6}, \mathrm{X}_{12}$, and $\mathrm{X}_{17}$ used in this analysis, and discussed later, are taken from Table 25 of this document.

${ }_{4}^{4}$ The tax, expenditure and community accessibility variables are expressed in $\log$ form to account for their suspected non-linear relationship to median property values. A one percentage point change in any of these variables is expected to have less of an influence on median property values at higher levels than at lower levels.

5To smooth out possible abberations in effective tax rates that might occur in a single year, a simple three year average is computed from 1958 to 1960 to represent the effective tax rate for municipal and school services in each community. Data on total tax collections for school purposes from all sources within each community are taken from the Governor's Committee on Education, [1960, pp. 48-49]. Data on the market value of taxable property came from Pennsylvania State Tax Equalization Board, [1961, pp. 28-29, 59]. Expenditure per capita is taken from Pennsylvania, Department of Internal Affairs, [1962]. Finally, data on nominal school and municipal tax rates, as well as the assessment ratios used to compute the effective property tax rate, are obtained from Pennsylvania, Dept. of Commerce, [1962].

${ }_{6}$ Non-property taxes are an important source of local government revenue in the Harrisburg area and to exclude them introduces a downward bias in the true tax cost of residing in a community. For example, the effective residential property tax rate mean for the fourteen communities studies is $12.3 \%$. When nonproperty tax sources are included, the mean effective tax rate for the Harrisburg area is $17.2 \%$.

iLocal residents may bear the burden of business taxes levied locally in the form of lower wage rates and/or higher prices for goods and services produced and sold locally. Of course, to the extent that local business taxes are exported to other communities they are not a direct burden to local residents. However, this upward bias in our measure of local tax rates is expected to cancel somewhat since other communities 
are also expected to export a share of their business taxes (i.e., local residents will pay higher prices for goods and services that they import). Moreover, the regression results will be unaffected if each community exports roughly the same proportion of local taxes to other communities.

- Using the dollar value of inputs as a measure of the level of real municipal and school services can be justified to some extent because the level of public and educational services is probably directly related to the level of resources used by the supplying jurisdictions.

"Traffic volume maps of the Harrisburg area were used to measure linear distances. See the Tri-County Regional Planning Commission, [Maps 1969, 17, 18, and 19].

10 The full results of the principle component analysis are not presented in this paper. For a complete discussion of the results see Premus, [1974, pp. 69-77].

11 The number of predetermined variables in the system (16) exceeds the number of observations (14) so ordinary least squares is inapplicable. To circumvent this difficulty principal component analysis is applied to the 16 predetermined variables to delineate clusters (components) of intercorrelated variables. $1 \mathrm{nX}$ and $\ln \mathrm{X}_{: 3}$ are then regressed on the five components, which are represented by basic variables in $\mathrm{X}_{4}, \mathrm{X}_{\tau}, \mathrm{X}_{12}$, $\mathrm{X}_{1: i}$, and $\mathrm{X}_{1 ;}$ respectively, to obtain $\ln \hat{\mathrm{X}}_{2}$ and $\ln \hat{\mathrm{X}}_{3}$. For a discussion of the application of the principal component model to the first stage in a 2SLS model, see Johnston, [1972, pp. 393-405].

1:It is important when applying the 2SLS model that the number of predetermined variables, in a simultaneous equation system, excluded from the property value equation exceeds the number of endogenous variables in the property value equation less one. If this condition is not met, consistent and unbiased estimates of the structural parameters in the 2SLS model cannot be obtained. For a discussion of the identification problem see Rao and Miller, [1971, pp. 212-220].

1:3 Oates measures local tax rates as the effective tax rate on real estate and confined his measure of municipal output to expenditures per pupil.

$1+\$ 669$ is the product of the regression coefficient for local taxes and the difference between the natural $\operatorname{logs}$ of 17 and 18 percent.

15:Police, fire and public health expenditures are deleted from municipal expenditures when measuring per capita municipal output. Unusually high expenditures on these items may be considered negative expenditures by taxpayers who have the option to locate in less troublesome communities. The adjustment improved the explanatory power of $\ln _{3}$ in the analysis.

16:The difference which individuals appear to evaluate equivalent tax burdens and public service flows might reflect relative ignorance of public service flows, tax burdens unrelated to benefits received, and/or a non-optimal mix of public services.

1-Community location is tested in $\log$ and non-log form without significantly altering the explanatory power of $\mathrm{X}_{4}$. The latter form is retained in the analysis to facilitate interpretation of the regression results.

18 Oates [1969, p. 966] found that $\$ 1,000$ in median family income increased property values by approximately $\$ 1,500$ in his study. The unusual importance of median family income as an explanatory variable in this test may be explained by the method of model specification. Variable $\mathrm{X}_{11}$ is the basic variable for a component which consists of a set of highly intercorrelated variables (variables $X_{5}$ through $X_{11}$ ). Thus, $\mathrm{X}_{11}$ is picking up the influence of six other variables. Moreover, the typical community in the Harrisburg area has a median family income of about $\$ 6,600$. A rise in median family income by $\$ 1,000$ represents approximately a $16 \%$ rise in the neighborhood quality index.

1:Buchanan [1950, pp. 583-599], demonstrated that fiscal advantages may accrue to the constituency in wealthier communities in the form of higher expenditures, lower taxes, or a combination of the two.

\section{REFERENCES}

Buchanan, James M. "Federalism and Fiscal Equity," American Economic Review, Vol. 40, (1950), pp. 583-99. Hyman, D. N., and Pasour, E. C. "Real Property Taxes, Local Public Services, and Residential Property Values," Southern Economic Journal, Vol. 29, (1973), pp. 601-11.

Johnston, J. Econometric Methods. New York: McGraw-Hill Book Company, Inc., 1972.

Kish, L. K., and Lansing, J. B. "Response Errors in Estimating the Value of Homes," American Statistical Association Journal, Vol. 49, (1954), pp. 520-532.

Oates, W. E. "The Effects of Property Taxes and Local Public Spending on Property Values: An Empirical Study of Tax Capitalization and the Tiebout Hypothesis," Journal of Political Economy, Vol. 77, (1969), pp. 957-971.

Pennsylvania, Department of Commerce, 1960 Property Tax Rates: County, Local and School Property Tax Rates for Selected Boroughs, Cities and Townships.

Pennsylvania, Department of Internal Affairs. Local Government Financial Statistics-1960, Release No. 24, 25, and 53, (1962), Harrisburg, Pennsylvania.

Pennsylvania, The Governor's Committee on Education, Educational Research Monograph No. 6, The Nobel Investment: A Statistical Study of Pennsylvania's Financial Support of Public Education, (December, 1960).

Pennsylvanic State Tax Equalization Board: 1960 Market Values, (June 30, 1960). 
Premus, Robert. "The Supply of Public Goods and Property Valuation in a System of Local Governments", Unpublished doctoral dissertation, Lehigh University, 1974.

Rao, Potluri, and Miller, Roger LeRoy. Applied Econometrics. California; Wadsworth Publishing Company, Inc., 1971.

Tiebout, Charles M. “A Pure Theory of Local Expenditures,” Journal of Political Economy, Vol. 64 (1956), pp. 416-424.

Tri-County Regional Planning Commission, Existing Conditions, Cumberland and Dauphin Counties, 1967. Tri-County Regional Planning Commission, Existing Conditions and Phase I Plan, Cumberland, Dauphin and Perry Counties, (1969), Maps 17, 18, and 19.

U.S. Department of Commerce, Bureau of the Census, United States Census of Housing: 1960, Vol. 1, States and Small Areas, part 7, Oklahoma-Tennessee. 